\title{
The Development of Integrated Biology-Entrepreneurship Learning Design Based STEAM
}

\author{
Linda Retnowati $^{1 凶}$, Sugianto Sugianto ${ }^{2}$, Siti Alimah ${ }^{2}$ \\ ${ }^{1}$ SMAN 11 Semarang, Indonesia \\ ${ }^{2}$ Pascasarjana, Universitas Negeri Semarang, Indonesia
}

\begin{tabular}{l}
\hline Article Info \\
\hline Article History : \\
Received August 2020 \\
Accepted September 2020 \\
Published August 2021 \\
\hline Keywords: \\
Critical Thinking, Learing \\
Design, Entrepreneurial \\
Interest, STEAM \\
\hline
\end{tabular}

\begin{abstract}
Biology learning design development is an important matter for teachers to be prepared. It is for the sake of realizing the $21^{\text {st }}$ education for the learners. Learning biology also involves the technology role and its implications to obtain innovative and beneficial products for broader people. This research aims to examine the validity and effectiveness of the development of integrated biology-entrepreneurship based on STEAM learning design on a material about the environmental changes to improve critical thinking skills and the entrepreneurial interest of the learners. The applied development procedures were ADDIE model. The developed learning design consisted of syllabus, lesson plan, learning source, worksheet, critical thinking test, and entrepreneurial interest. The findings showed that (1) the validity of the learning was deemed valid and practical by the expert judgment; (2) the effectiveness of the learning design was proven able to improve the learners' critical thinking skills with a percentage of $84 \%$, with a sufficient $N$-Gain category and high category of entrepreneurial interest average improvement with a score of 77 . The paired sample $t$-Test shows that $t_{\text {count }}>t_{\text {table. }}$. Thus, it could be concluded that there was a significant difference between the critical thinking skills and the entrepreneurial interest. Based on the findings, it could be concluded that the biology learning with a material about the environmental changes integrated by entrepreneurship based on STEAM had highly met the validity criteria. It could improve the critical thinking skill and the entrepreneurial interest of the learners.
\end{abstract}

$\triangle$ correspondence

SMAN 11 Semarang, Indonesia

Gg. XIV, RT.01/RW.01, Lamper Tengah, Kecamatan Semarang

Selatan, Kota Semarang, Jawa Tengah 50248

E-mail: lindaretnowati@gmail.com 


\section{INTRODUCTION}

The changes of 2013 curriculum, as seen in its core and basic competences, deal with the primary requirement for the learners to develop their skills in this digital era especially critical thinking and competitive skills for real working word as the demand of the $21^{\text {th }}$ century-biology learning. The learners' skills in thinking and acting are not separated from the interaction of the individual and his environment as the source of learning (Aulia et al., 2018). Besides that, the ideal biology learning emphasizes on phenomenological review in biology context completely and meaningfully. It involves the roles of technology and their implicatures to produce innovative and beneficial products for broader people (Ardhiansyah et al., 2017).

The reality on the field about biology learning shows emphasis on the requirement for the learners to meet the cognitive target based on the Core Competence. It is also found the implementation of the existing learning source is not optimal. It leads to less optimal the critical thinking skills and creativity of the learners to solve problems about biology and to produce various products representing the entrepreneurial interest. Based on the latest data, Indonesia is in the $70^{\text {th }}$ rank out of 78 participating countries in the fields of literacy, mathematics, and science (OECD, 2018).

The development of biology learning design with the integration of science-based entrepreneurship, technology, art, technique, and mathematics (STEAM) on the material about environmental changes is expected to provide the solution of biology learning challenges in $21^{\text {th }}$ century. The development of project learning design is a learning model that requires active participation of the learners. It leads to problem solving and to develop the thinking skills and learning achievement of the learners (Annisa, 2018). The project based learning model could also be integrated through STEM-Entrepreneur approach. It could train the scientific literacy and entrepreneurial interest of the learners (Ardhiansya et al., 2019). It is in line with Aristantia (2017) that the implementation of STEAM could improve conceptual cognition and to find out the characteristics profiles of JHS learners. The implementation of STEAM in Indonesia's curriculum could train the skills and talents of the learners to face challenges of $21^{\text {st }}$ century (Danang, 2015). The STEAM conceptual application, by creating entrepreneurship-oriented product, makes specific characteristics by implementing STEAM based the worksheet. It was done by Septiani (2017 and Sulistiyowati et al. (2018). They focused on STEM integrated aspects in the learning materials without the existence of the applied products in daily lives.

\section{METHOD}

The applied developmental method in this research was ADDIE from McGriff (2000) modified by Aldoobie (2015). The method consisted analyzing the necessity, the teachers' designing performance, and the learners, learning instrument, developing or realizing the product design in the form of product to be tested, validated by the experts, practiced, and tested in a limited scope for the learners at XII-7 Science and Mathematics class of 11 Public JHS Semarang, implementing the learning design to be massively tested for the learners at 2 classes of X Science and Mathematics program taken by purposive sampling, and evaluating the assessment promotion by using the multiple choice test instrument to measure the critical thinking skills and the non-test in the form of questionnaire to measure the entrepreneurial interest. The data analysis in this research used $N$ Gain test and continued by paired sample t-test. The learning design development test is seen in Figure 1.

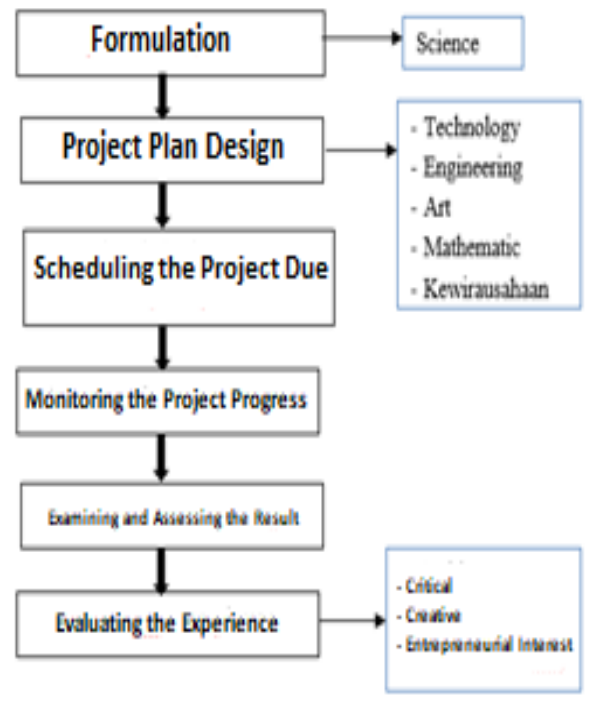

Figure 1. The Development of Integrated BiologyEntrepreneurship Learning Design based on STEAM 


\section{FINDINGS AND DISCUSSION}

\section{Learning Design Validity}

The developed learning design consisted of syllabus, lesson plan, learning source, worksheet, critical thinking test, and entrepreneurial interest. There were three main components in this validation. They were reliability, diction, and display. The validity was done by expert lecturers and practitioners as shown in Figure 1.

Table 1. The Validity of the Development of Integrated Biology-Entrepreneurship Learning Design based on STEAM by Experts and Practitioners.

\begin{tabular}{llllll}
\hline \multirow{2}{*}{$\begin{array}{l}\text { Number } \\
\end{array}$} & $\begin{array}{l}\text { The Learning Design } \\
\text { Development Components }\end{array}$ & $\begin{array}{l}\text { Expert } \\
\text { Validator }\end{array}$ & $\begin{array}{l}\text { Practitioner } \\
\text { Validator }\end{array}$ & Average & Criteria \\
\hline 1 & Syllabus & 96.0 & 96.0 & 96.0 & Very valid \\
2 & Lesson Plan & 97.3 & 96.0 & 96.7 & Extremely Valid \\
3 & Learning Materials & 95.6 & 96.7 & 96.1 & Extremely Valid \\
4 & Worksheet & 97.8 & 95.6 & 96.7 & Extremely Valid \\
5 & Critical Thinking Skills & 94.5 & 92.7 & 93.6 & Extremely Valid \\
6 & The entrepreneurial interest scale & 98.0 & 98.0 & 98.0 & Extremely Valid \\
7 & The creativity measurmeent tools & 98.0 & 98.0 & 98.0 & Extremely Valid \\
& Average & & & 96.4 & Extremely Valid \\
\hline
\end{tabular}

In Table 1 , it shows the internal validity result of the developed design. It was valid so it war reliable to be used as the guidance to implement biology learning with a material about environmental changes integrated by STEAM based entrepreneurship.

The external validity found in the critical thinking skill test was seen from the validity of each question item, the difference power, and the reliability. The data analysis applied product moment correlation of 40 question items that met the criteria of validity, power of the difference, and reliability.

The learning design development that obtained excellent validation was influenced by several factors. They were: (1) the applied indicators of the instrument validity that met the requirements of the developed learning design, (2) the appropriate content materials to the problem formulation principles, (3) the use of brief, simple, understandable, and practical language for the learners and the teachers, (4) the information content in the form of data display to be processed by the learners, (5) the opportunity to make learners able to process the content information about environmental changes. It is supported by Dewi (2016) and Wijayanti (2017). To obtain an excellent validity, then the developed products should meet the criteria off the validator judgments and to consider the complexity of the learners' reasoning skills and the teachers' competence skills who promoted the learning products.
The learning design was adjusted to the learner's environments. The quality of local potentials provided positive value for the learning instrument validity. It is also supported by Apriliana (2018) she found that a learning design could encourage learners to actively explore in overcoming daily life problems. The developed biology learning design is very important to realize the $21^{\text {st }}$ century skills for the learners (Listianingrum et al., 2018 \& Setiyadi, 2018).

The effectiveness of the learning design to improve the Critical Thinking Skills and the Entrepreneurial Interest.

The learning design effectiveness could be seen from the Normalized Gain of the critical thinking skill data and the entrepreneurial Interest between the pre- and post- intervention conditions of the biology learning with a material of integrated environment-entrepreneurship based on STEAM. It is shown in Table 2 and Table 3.

Table 2. Results Critical Thinking Skills

\begin{tabular}{lll}
\hline & Pretest & Post-test \\
\hline Average & 71 & 84 \\
$N$-gain & 0.44 & \\
Categories & Sufficient & \\
\hline
\end{tabular}

Table 3. The Results of Entrepreneurial Interest

\begin{tabular}{lcl}
\hline & Pre & Post \\
\hline Average & 64 & 77 \\
$N$-gain & 0.36 & \\
Categories & Sufficient & \\
\hline
\end{tabular}


The, a paired sample t-test was conducted as seen in Table 4 and Table 5.

Table 4. Paired Sample T-test of the Critical Thinking Skill

\begin{tabular}{llllll}
\hline Condition & Average & $\mathrm{SD}$ & $\mathrm{t}_{\text {count }}$ & $\mathrm{dk}$ & $\mathrm{t}_{\text {table }}$ \\
\hline Pre-test & 71 & 8.37 & \multirow{2}{*}{12.105} & \multirow{2}{*}{71} & \multirow{2}{*}{1.67} \\
Post-test & 84 & 8.37 & & & \\
\hline
\end{tabular}

Table 5. Paired T-test of the Entrepreneurial Interest

\begin{tabular}{|c|c|c|c|c|c|}
\hline Condition & Average & SD & $t_{\text {count }}$ & $\mathrm{dk}$ & Sign \\
\hline Pre & 64 & 3.057 & 11.707 & 71 & 0.000 \\
\hline Post & 77 & 4.649 & & & \\
\hline
\end{tabular}

The analysis showed the developed learning design was effective to improve the critical thinking skills and entrepreneurial interest of the learners.

The improvement of the learners' critical thinking skills could be seen in Table 6 .

Table 6. The Skill Improvement of Each Critical Thinking Aspect

\begin{tabular}{llllll}
\hline Number & Aspects & Pre-test & Post-test & Gain & Categories \\
\hline 1 & Elementary clarification & 83 & 84 & 0.07 & Low \\
2 & The basis for the decision & 90 & 91 & 0.17 & Low \\
3 & Inference & 64 & 82 & 0.49 & Sufficient \\
4 & Advance clarification & 79 & 88 & 0.41 & Sufficient \\
5 & Supposition and integration & 65 & 83 & 0.50 & Sufficient \\
& Total & 71 & 84 & 0.44 & Sufficient \\
\hline
\end{tabular}

The analysis of each indicator was used to find out the improvement of the critical thinking skill. It dealt with:

(1) The elementary clarification.

Its indicators were focusing on the questions, analyzing the arguments, answering the challenging questions. The learning design consisted of problems concerning with the environment and its impacts to daily lives. Then, they were given through worksheets that required the learners to solve the problems critically. This is supported by Apriliana (2018) that STEAM approach encourages learners to obtain more knowledge by actively explore the real world challenges and daily life problems.

(2) Giving opportunity to decide.

This indicator deals with the credible consideration of a source and consider the observation results. Dealing with worksheet, the learners were directed to understand a problem concerning with an environmental change so they could consider the observation results they obtained for the sake of problem-solving solution. The critical thinking skill covers accessing, analyzing, synthesizing, informing skills that could be taught, trained, and mastered (Hidayati, 2017).

(3) Concluding or Inferencing

It deals with making a deduction, induction, and conclusion. The provision of a structured environmental changing case and an understandable instruction for the learners in the worksheet made them trained to make a conclusion from an on-going phenomenon. The $\mathrm{N}$-gain analysis result of the normalized aspect concluded several categories had been sufficient. It showed that the developed learning design could improve the skills to make conclusion or inference. The statement is in line with Kowiyah (2013). She argues that critical thinking skill is a cognitive skill to obtain science and understanding to make a deductive, inductive, or evaluative decision comprehensively.

(4) Advance Clarification

This indicator identifies the term and refers on the unstated assumption. The learning design was created to direct and train learners to think critically on the material about the environmental changes. The accessing, analyzing, synthesizing, and informing skills were important to teach as the critical thinking skills to be mastered (Hidayati, 2017).

(5) Supposition and Integration.

This indicator is about consideration and reasoning of an assumption and an integration in making an action or decision. The project learning model that direct learners to produce a product could provide positive influence in making an action or decision. It is in line with the project-based learning concept. According to Sastrika et al. (2013), active learners who created innovative works to solve problems and take decision could improve their critical thinking skills. 
The value of entrepreneurial interest should consider several typical criteria. By considering the external and internal factors, the entrepreneurial interest could be realized in the learning process and the recycling process of the learners' surrounding environments. The entrepreneurial interest of the learners could be seen in Table 7 .

Table 7. The average of the entrepreneurial interest.

\begin{tabular}{lllll}
\hline & Pre (\%) & & Post (\%) \\
\hline Aspects & in score & Criteria & in score & Criteria \\
\hline Interested & 65 & High & 83 & Very High \\
Motivation & 61 & Low & 78 & High \\
Enjoy & 75 & High & 78 & High \\
Expectation & 59 & Low & 72 & High \\
\hline Total & 64 & High & 77 & High \\
\hline
\end{tabular}

The analysis of each aspect was used to find out the entrepreneurial interest improvements. They were:

\section{(1). Interested}

The collaborated-project learning design with biology and entrepreneurship courses had not been promoted previously. Thus, it made the learners interested. This interest in creating products could improve the learners' entrepreneurial interest. It is as proven by Sudarmin et al (2016); Sumarti et al., (2018); Sunarya et al., (2018) that chemoenterpreneurship-based learning by integrating entrepreneurship and chemistry courses in creating a competitive product with its local potential could improve the learners' care and interest to have entrepreneurship.

(2). Motivation

The interest of the learners in the project to create craft made them motivated. Thus, it led to entrepreneurial interest realization. The learning design trained the learners individually and independently to create the products with primary materials from their surrounding wastes. It is supported by Slameto (2010), Daryanto (2012), and Munawer et al. (2018). They stated that affection and attitudes concerning with entrepreneurship in the learning activity motivated them to do entrepreneurship.

(3). Enjoy

The products of the learners were offered online through Instagram. The uploaded products were captioned with an interesting description. Thus, it would attract and would be a promotion so that the products could be sold. The numbers of the likes by the followers toward the offered products in Instagrams would be the assessment of the product. It would deem whether the products successfully attracted the buyers or not. This entrepreneurial interest in the learning activity, According to Anafiyah et al. (2015) and Suryana et al. (2018) did not only emphasize on the applicative skills of the entrepreneurial interest but also communication skills to broader people about the entrepreneurial activit y scope done by the learners.

(4) Intention.

The developed learning design encourage learners to understand more about the entrepreneurship such as analyzing the strength, the weakness, the opportunity, and the threat (SWOT) in creating the products with Semarang signature and using waste as the primary materials. According to Sudarmin et al. (2016) \& Sumartini et al (2018), the skills for analyzing the strength, the weakness, the opportunity, and the threat in creating a learning product are correlated to the intention to be entrepreneur in the future.

\section{CONCLUSION}

The development of the integrated biologyentrepreneurship learning design based on STEAM with a material about the environmental change had met the validity and effectiveness criteria to improve the critical thinking skills and the entrepreneurial interest of the learners.

\section{REFERENCES}

Aldoobie, N. (2015). ADDIE Model. American International Journal of Contemporary Research. Vol. $5,68-72$.

Anafiyah, K., Sulistiyowati, E \& Susilawati, L. (2015). Pengembangan Modul Ekosistem Berorientasi Kewirausahaan untuk SMA/MA. Jurnal Karunia. 6(1), 72-77.

Annisa, R., Effendi,M., Damris, D., (2018). Peningkatan Kemampuan Berpikir Kreatif Siswa Dengan Menggunakan Model Project Based Learning Berbasis STEAM pada Materi asam dan Basa Di SMAN 11 Kota Jambi. Journal of The Indonesia Society of Integrated Chemistry. 10(2), 1-11.

Aristantia, G., (2017). Penerapan Science Technology and Engineering Art Mathematicc Pada Tema Air dan Kita untuk Meningkatkan Penguasaan Konsep dan Mengetahui Profil Karakter Peserta Didik SMP. Repository UPI-edu. 
Apriliana, M. R., Ridwan, A., Hadinugrahaningsih, T., \& Rahmawati, Y. (2018). Pengembangan Soft Skills Peserta Didik melalui Integrasi Pendekatan Science, Technology, Engineering, Arts, and Mathematics (STEAM) dalam Pembelajaran Asam Basa. JRPK: Jurnal Riset Pendidikan Kimia, 8(2), $101-110$.

Ardhiansyah, F., Mulyani, S., Alimah, S. (2019). The development of STEM-E based Biology LearningTools to Train Students' Scientific Literacy and Enterpreneurial Interest. Proceedings International Science (ISET). Unnes.

Carnawi., Sudarmin \& Wijayanti, N. (2017). Application of Project Based Learning (PBL) Model for Materials of Salt Hydrolisis to Encourge Student's Entrepreneurship Behaviour. International Journal of Active Learning. 2(1), 50-58.

Danang, A.W. Karmila N., Rizqi M. (2015). Implementai Pembelajaran Berbasis STEAM (Science, Technology, Engineering, Art, Mathematics) Pada Kurikulum Indonesia. Prosiding Seminar Nasional Fisika dan Aplikasinya. Universitas Padhjajaran.

Daryanto. (2012). Pendidikan Kewirausahaan. Yogyakarta: Gava Media.

Dewi, F.I. (2016). Validitas Perangkat Pembelajaran Berbasis Literasi Sains Pada Materi Virus Kelas X SMA. Jurnal Bioedu. Vol.5, 166-173.

Hidayati, A.U. (2017). Melatih Keterampilan Berpikir Tingkat Tinggi dalam Pembelajaran Matematika pada Siswa Sekolah Dasar. Jurnal Pendidikan dan Pembelajaran Dasar.4(2), 143-156.

Kowiyah. (2012). Kemampuan Berpikir Kritis. Jurnal Pendidikan Dasar. 3(6), 175-179.

Listianingrum, N., Maridi \& Aminah, S.N. (2018). The Effect of Guided Inquiry Learning Model Toward Sevent Grade Student's Scientific Literacy on The Classification of Living Things Material. Proceedings International Conferency on Research, Implementation and Educaton of Mathematic and Science. Hlm 85-88.

McGriff, S.J. (2000). Instructional System Design (ISD). Using the ADDIE Model. Pensilvania: Penn State University.

Munawar, A \& Supriatna, N. (2018). Pengaruh Sikap dan Motivasi terhadap Minat Berwirausaha. Jurnal Kajian Pendidikan Ekonomi dan Ilmu Ekonomi. 2(1), 14-23.

Nofiana, M., Sudjana \& Puguh. (2014). Pengembangan Instrumen Evaluasi Two-Tier Multiple Choice Question untuk Mengukur Keterampilan Berpikir
Tingkat Tinggi pada materi Kingdom Plantae. Jurnal Inkuiri. 3(II), 60-74.

OECD. (2016). PISA. 2015. Result in focus. Paris: OECD.

Sastrika, k.A, Sadia, W., \& Muderawan, W.I. (2013). Pengaruh Model Pembelajaran Berbasis Proyek Terhadap Pemahaman Konsep Kimia Dan Keterampilan Berpikir Kritis. E-Journal Program Pascasarjana Universitas Pendidikan Ganesha Program Studi IPA. 3(1), 1-10.

Septiani, A. (2017). Penerapan Assesmen Kinerja dalam Pendekatan STEM (Sains, Teknologi, Engineering, dan Matematika) unutk Mengungkap Keterampilan Proses Sains. Prosiding Seminar Nasional "Isu- Isu Kontemporer Sains, Lingkungan, dan Inovasi Pembelajaran. Hlm 654659.

Setiyadi, M.W. (2018). Desain Model Pengembangan Perangkat pembelajaran.

Slameto, (2015). Belajar dan Faktor-Faktor yang Mempengaruhinya. Jakarta: Bina Aksara.

Stobaugh, R. (2013). Assesing Critical Thinking in Middle and High Schools: Meeting the Common Core. New York: Rouledge.

Sulistyowati, Abdurrahman and Jalmo, T. (2018). The Effect of STEM-Based Worksheet on Student's Science Literacy. Jurnal Keguruan dan Ilmu Tarbiyah. Vol.3, 89-96.

Sudarmin., Febu, R \& Sumarni, W. (2016). Development of Etnoscience Approach in The Module Theme Substance Additives to Improve the Cognitive Learning Outcome and Student's Entrepreneurship. The 3rd International Conference on Mathemathic, Science and Education 2016, 1-14.

Sunarya, R. A., Supartono., Sumarti, S.S. (2018). Analisis Hasil Belajar dan Minat Wirausaha Siswa Menggunakan Bahan Ajar Berorientasi Chemoentrepreneurship. National Scientific Journal of Unnes. 12(1), 1-10.

Wijaya, A.D, Kamila,N \& Amalia, M.R. (2015). Implementasi Pembelajaran Berbasis STEAM (Science, Technoloy, Engineering, Arts, and Mathematic) pada Kurikulum Indonesia. Prosiding Seminar Nasional Fisika dan Aplikasinya. Hlm 8588.

Wiyanti, W. (2017). Pengembangan Perangkat Pembelajaran Biologi Berbasis Lingkungan dengan Setting Modified Inquiry untuk Meningkatkan Karakter dan Pemahaman Konsep Siswa SMA. Jurnal Ilmiah Pendidikan dan Pembelajaran. Vol.1, 1-9.ence. 2(24):174-182 